\title{
HHV8-related lymphoid proliferations: a broad spectrum of lesions from reactive lymphoid hyperplasia to overt lymphoma
}

Blanca Gonzalez-Farre ${ }^{1}$, Daniel Martinez ${ }^{1}$, Monica Lopez-Guerra ${ }^{1}$, Marc Xipell ${ }^{2}$, Ester Monclus ${ }^{2}$, Jordina Rovira ${ }^{3}$, Felipe Garcia ${ }^{4}$, Armando Lopez-Guillermo ${ }^{3}$, Luis Colomo ${ }^{5}$, Elias Campo ${ }^{1}$ and Antonio Martinez ${ }^{1}$

${ }^{1}$ Department of Pathology, Hospital Clinic, Institut d'Investigacions Biomediques August Pi I Sunyer (IDIBAPS), University of Barcelona, Barcelona, Spain; ${ }^{2}$ Department of Geriatrics, Hospital Clinic, University of Barcelona, Barcelona, Spain; ${ }^{3}$ Department of Hemathology, Hospital Clinic, Institut d'Investigacions Biomediques August Pi I Sunyer (IDIBAPS), University of Barcelona, Barcelona, Spain; ${ }^{4}$ Department of Infectious Diseases, Institut d'Investigacions Biomediques August Pi I Sunyer (IDIBAPS), Hospital Clinic, University of Barcelona, Barcelona, Spain and ${ }^{5}$ Department of Pathology, Hematopathology Section, Hospital del Mar, Institut Mar d'Investigacions Mèdiques (IMIM), University Pompeu Fabra, Barcelona, Spain

Human herpesvirus 8 (HHV8)-associated lymphoid proliferations are uncommon and poorly characterized disorders mainly affecting immunosuppressed patients, especially with HIV infection. They encompass different diseases with overlapping features that complicate their classification. In addition, the role of HHV8 in reactive lymphoid hyperplasia is not well known. To analyze the clinicopathological spectrum of these lesions, we have reviewed 66 biopsies of 61 patients with HHV8 infection. All cases were also investigated for Epstein-Barr virus (EBV) and HIV infection. We identified $13(20 \%)$ cases of HHV8-related reactive lymphoid hyperplasia, $2(3 \%)$ HHV8 plasmablastic proliferations of the splenic red pulp, $28(42 \%)$ multicentric Castleman disease, $6(9 \%)$ germinotropic lymphoproliferative disorders, and 17 (26\%) HHV8-related lymphomas. As expected, the pathologic subtype was predictive of overall survival $(P<0.05)$. Forty-seven of our cases were HIV positive $(77 \%)$. In addition to the classical presentation of the different entities, we identified novel and overlapping features. Reactive HHV8 proliferations were frequently associated with systemic symptoms but never progressed to overt HHV8-positive lymphoma. Two cases had a plasmablastic proliferation limited to spleen. Eight cases of multicentric Castleman disease had a previously unrecognized presentation shortly after the diagnosis of HIV infection, six cases had cavity effusions, and three showed plasmablast enriched proliferations. One germinotropic lymphoproliferative disorder was EBV negative and three occurred in HIV-positive patients, who had distinctive clinical and morphological features. Two of the HHV8-related lymphomas did not fulfill the criteria for previously recognized entities. All these findings expand the clinical and pathological spectrum of HHV8-related lymphoid proliferations, which is broader than current recognized.

Modern Pathology (2017) 30, 745-760; doi:10.1038/modpathol.2016.233; published online 13 January 2017

Human herpesvirus 8 or Kaposi sarcoma-associated herpesvirus (HHV8/KSHV) is a $\gamma$-herpesvirus that was first identified as the etiological agent of Kaposi sarcoma in $1994 .{ }^{1}$ Shortly after, it has been associated with different B-cell proliferations such as primary effusion lymphoma, ${ }^{2}$ and its solid variant, ${ }^{3}$

Correspondence: Dr B Gonzalez-Farre, MD or Dr A Martinez, MD, PhD, Pathology Department, Hospital Clinic, Villarroel 170, 08036 Barcelona, Spain.

E-mail: mbgonzal@clinic.ub.es or antonmar@clinic.ub.es

Received 15 September 2016; revised 24 November 2016; accepted 25 November 2016; published online 13 January 2017 as well as most cases of multicentric Castleman disease, ${ }^{4}$ particularly in HIV-positive patients. ${ }^{5}$ While most of these lesions occur in the setting of HIV infection in HHV8 endemic areas, they may be also seen in other immunocompromised conditions. ${ }^{6}$ In 2002, germinotropic lymphoproliferative disorder was identified as a localized HHV8-related disease associated with Epstein-Barr virus (EBV) coinfection in immunocompetent patients. ${ }^{7}$ The updated 2016 World Health Organization classification includes the new category of HHV8-positive diffuse large B-cell lymphoma, not otherwise specified expanding 
Table 1 Main clinicopathological features of all cases

\begin{tabular}{|c|c|c|c|c|c|c|c|c|}
\hline & \multirow[b]{2}{*}{$R H$} & \multirow[b]{2}{*}{$P B P-R P$} & \multicolumn{2}{|c|}{ Castleman disease } & \multirow[b]{2}{*}{$G L P D$} & \multicolumn{3}{|c|}{ Lymphomas } \\
\hline & & & $M C D$ & $P B R-M C D$ & & $P E L$ & ecPEL & NOS \\
\hline \multicolumn{9}{|l|}{ Demographics } \\
\hline$N$ & 13 & 2 & 25 & 3 & 5 & 9 & 6 & 2 \\
\hline Age (range), years & $37(20-44)$ & $40(36-44)$ & $45(20-80)$ & $30(22-37)$ & $47(27-86)$ & $49(39-76)$ & $45(32-62)$ & $53(44-63)$ \\
\hline Male/female, $n$ & $13 / 0$ & $2 / 0$ & $22 / 3$ & $2 / 1$ & $4 / 0$ & $9 / 0$ & $6 / 0$ & $2 / 0$ \\
\hline $\mathrm{HIV}, n$ & 13 & 2 & 18 & 3 & 3 & 6 & 6 & 1 \\
\hline \multicolumn{9}{|l|}{ Extent of disease } \\
\hline Localized, $n(\%)$ & $2(15)$ & $2(100)$ & $4(16)$ & - & $2(40)$ & - & - & $1(50)$ \\
\hline Multiple sites, $n(\%)$ & $10(77)$ & & $17(68)$ & $3(100)$ & $3(60)$ & - & 5 & $1(50)$ \\
\hline Splenomegaly, n (\%) & $4(31)$ & $2(100)$ & $11(44)$ & $3(100)$ & $2(40)$ & - & $3(50)$ & $2(100)$ \\
\hline Effusions, $n(\%)$ & $3(23)$ & - & $4(16)$ & $2(67)$ & $1(20)$ & 100 & - & $1(50)$ \\
\hline B symptoms, $n(\%)$ & $7(54)$ & $1(50)$ & $19(76)$ & $3(100)$ & $3(60)$ & $1(11)$ & $4(67)$ & $2(100)$ \\
\hline \multicolumn{9}{|l|}{ Management } \\
\hline Only cART, $n(\%)$ & $10(77)$ & - & $3(12)$ & - & - & - & - & - \\
\hline Immunotherapy, $n(\%)$ & - & & $3(12)$ & & & & & \\
\hline Chemotherapy, $n(\%)$ & $3(23)$ & $1(50)$ & $13(52)$ & $2(67)$ & $4(80)$ & $9(100)$ & $5(84)$ & $1(100)$ \\
\hline \multicolumn{9}{|l|}{ Course } \\
\hline Complete remission, $n(\%)$ & $11(85)$ & $1(50)$ & $16(76)$ & $2(67)$ & $2(50)$ & - & $1(17)$ & $1(50)$ \\
\hline Relapse, $n(\%)$ & - & - & - & & - & $1(11)$ & - & - \\
\hline Progressive disease, $n(\%)$ & - & - & $4(20)$ & & $125)$ & $7(78)$ & $3(50)$ & $1(50)$ \\
\hline Histologic transformation, $n(\%)$ & - & - & $1(5)$ & & - & - & - & - \\
\hline \multicolumn{9}{|l|}{ Outcomes } \\
\hline Died of disease, $n(\%)$ & - & $1(50)$ & $4(18)$ & - & - & $7(78)$ & $3(50)$ & $1(50)$ \\
\hline Died of unrelated cause, $n(\%)$ & $1(8)$ & - & $3(14)$ & $1(33)$ & - & - & - & $1(50)$ \\
\hline Median (range) follow-up, months & $38(5-95)$ & $19(0-38)$ & $14(0-184)$ & $33(0-64)$ & $11(1-46)$ & $2(0-59)$ & $5(1-35)$ & $24(0-34)$ \\
\hline
\end{tabular}

Abbreviations: cART, combined antiretroviral therapy; ecPEL, extracaviatry primary effusion lymphoma; GLPD, germinotropic lymphoproliferative disorder; HIV, human immunodeficiency virus; MCD, multicentric Castleman disease; NOS, not otherwise specified; PBR-MCD, plasmablastrich multicentric Castleman disease; PBP-RP, plasmablastic proliferation of the splenic red; pulpPEL, primary effusion lymphoma; RH, reactive follicular hyperplasia.

the spectrum of HHV8-driven malignant plasmablastic proliferations. ${ }^{8}$

In addition to these well-characterized HHV8related lymphoproliferative disorders, occasional cases with atypical and overlapping features among entities have been recognized such as lesions intermediate between multicentric Castleman disease and germinotropic lymphoproliferative disorder in HIV-positive patients ${ }^{9}$ or cases of germinotropic lymphoproliferative disorder that progress to highgrade EBV and HHV8-positive lymphoma. ${ }^{10}$ These cases represent diagnostic challenges and suggest that the spectrum of the HHV8-related lesions may not be fully characterized. On the other hand, contrary to the well identified EBV-associated reactive hyperplasia with favorable outcome, especially under certain immunodeficiency conditions, ${ }^{11}$ the prevalence and clinical meaning of HHV8 infection in reactive lymphadenitis have not been well recognized.

The aims of this study were to characterize the pathologic and clinical features of the whole spectrum of HHV8-related lymphoid lesions in a large cohort of cases from reactive hyperplasia to overt lymphomas. Our results expand the spectrum of
HHV8-positive lymphoproliferative disorders with the identification of novel lesions and previous unrecognized clinical and pathological manifestations of the well-defined entities.

\section{Material and methods}

\section{Patients and Samples}

All HHV8-related lymphoid proliferations with available tissue biopsies were collected from the files of Pathology Departments of the Hospital Clinic and Hospital del Mar, Barcelona, Spain between 2000 and 2015. The initial selection was obtained by an electronic search in laboratory informatics systems for 'HIV' and 'reactive lymphoid hyperplasia', 'Castleman disease' and 'primary effusion lymphoma' and for 'HHV8'. Unicentric cases of hyaline-vascular Castleman disease and cases of isolated Kaposi sarcoma were excluded. We found a total of 66 cases, including 13 cases of reactive lymphadenitis with scattered HHV8-positive lymphoid cells. All the cases were reviewed and reclassified based on morphological and phenotypic features. Available clinical data were collected from 


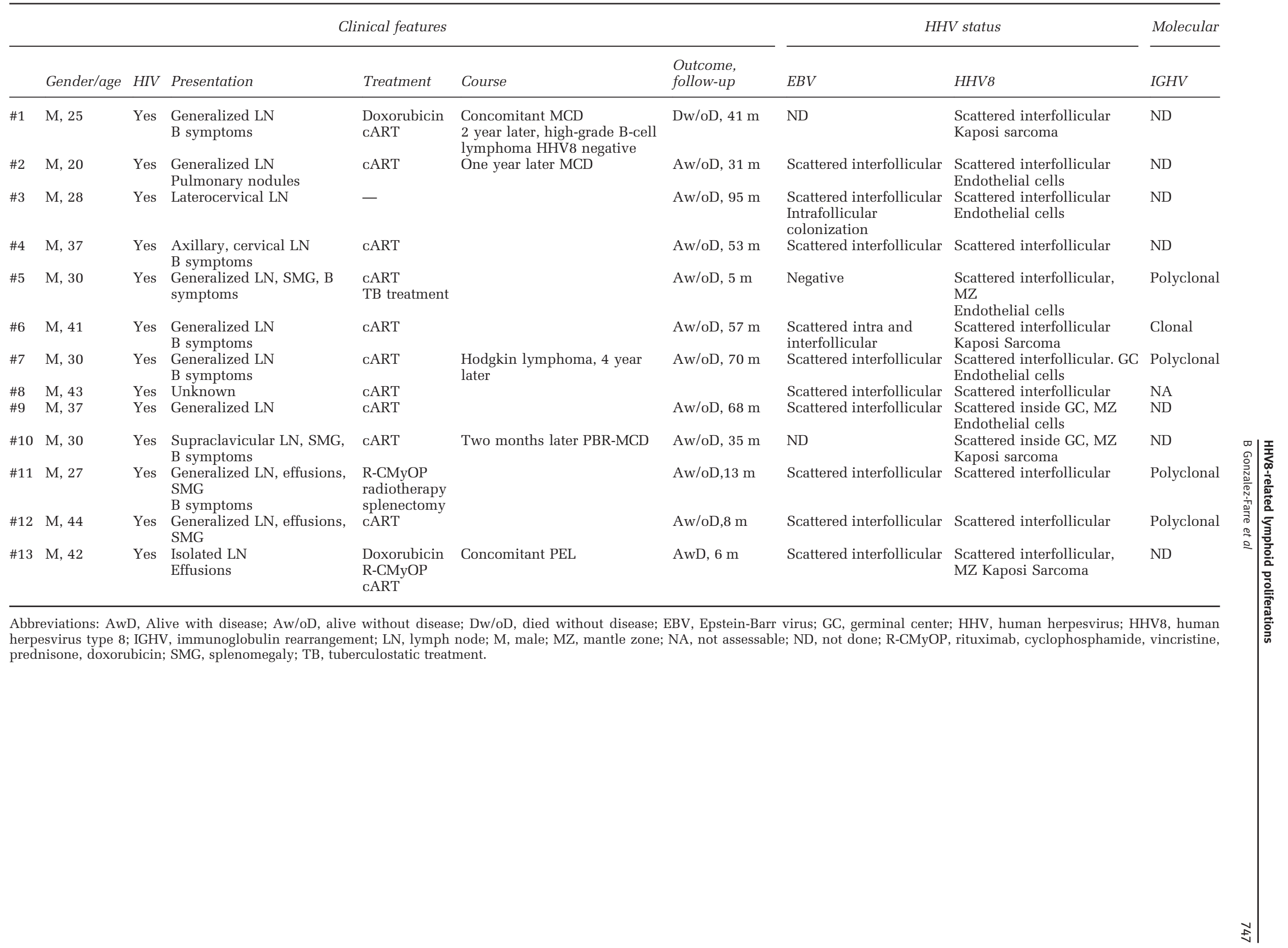


Table 3 Main clinicopathological features of multicentric Castleman disease

\begin{tabular}{|c|c|c|c|c|c|c|c|c|c|}
\hline \multicolumn{7}{|c|}{ Clinical features } & \multicolumn{2}{|c|}{ HHV status } & \multirow{2}{*}{$\begin{array}{l}\text { Molecular } \\
\text { IGHV }\end{array}$} \\
\hline & Gender/age & $H I V$ & Presentation & Treatment & Course & $\begin{array}{l}\text { Outcome, } \\
\text { follow-up }\end{array}$ & $E B V$ & $H H V 8$ & \\
\hline \#14 & M, 55 & Yes & $\begin{array}{l}\text { Inguinal, laterocervical LN, } \\
\text { HSMG }\end{array}$ & Steroids & & $\mathrm{DwD}, 1 \mathrm{~m}$ & Negative & $\mathrm{MZ}$ & NA \\
\hline \#15 & $\mathrm{M}, 47$ & Yes & Generalized LN, B symptoms & Unknown & Unknown & Unknown & $\begin{array}{l}\text { Scattered } \\
\text { interfollicular } \\
\text { Single } \\
\text { intrafollicular } \\
\text { coinfection with } \\
\text { HHV8 }\end{array}$ & $\begin{array}{l}\text { MZ, GC } \\
\text { Single } \\
\text { intrafollicular } \\
\text { coinfection with } \\
\text { EBV }\end{array}$ & Polyclonal \\
\hline$\# 16$ & $\mathrm{M}, 34$ & Yes & Unknown & Unknown & & $\begin{array}{l}\text { Dw/oD, } \\
51 \mathrm{~m}\end{array}$ & Negative & MZ, GC & Polyclonal \\
\hline$\# 1$ & M, 25 & Yes & $\begin{array}{l}\text { Generalized LN, tonsil } \\
\text { enlargement, HSMG } \\
\text { B symptoms }\end{array}$ & $\begin{array}{l}\text { cART } \\
\text { Doxorrubicin }\end{array}$ & $\begin{array}{l}\text { Concomitant RH and } 2 \text { years } \\
\text { later high-grade B-cell } \\
\text { lymphoma HHV8- }\end{array}$ & $\begin{array}{l}\mathrm{Dw} / \mathrm{oD} \\
42 \mathrm{~m}\end{array}$ & $\begin{array}{l}\text { Scattered } \\
\text { interfollicular }\end{array}$ & $\begin{array}{l}\text { MZ, GC, } \\
\text { interfollicular } \\
\text { Kaposi Sarcoma }\end{array}$ & Polyclonal \\
\hline$\# 17$ & M, 36 & Yes & $\begin{array}{l}\text { Generalized LN, SMG, B } \\
\text { symptoms }\end{array}$ & $\begin{array}{l}\text { R-CP } \\
\text { cART }\end{array}$ & & $\begin{array}{l}\text { Aw/oD, } \\
39 \mathrm{~m}\end{array}$ & $\begin{array}{l}\text { Scattered } \\
\text { interfollicular }\end{array}$ & $\begin{array}{l}\text { MZ, GC } \\
\text { Kaposi Sarcoma }\end{array}$ & Polyclonal \\
\hline$\# 18$ & $\mathrm{M}, 43$ & Yes & $\begin{array}{l}\text { Generalized LN } \\
\text { Effusions }\end{array}$ & $\begin{array}{l}\text { Doxorubicin and } \\
\text { Rituximab }\end{array}$ & 5 months later PEL & DwD, $10 \mathrm{~m}$ & $\begin{array}{l}\text { Scattered } \\
\text { interfollicular }\end{array}$ & $\begin{array}{l}\text { MZ, GC } \\
\text { Kaposi Sarcoma }\end{array}$ & Polyclonal \\
\hline$\# 19$ & $\mathrm{M}, 43$ & Yes & B symptoms & $\begin{array}{l}\text { cART } \\
\text { CHOP }\end{array}$ & & $\begin{array}{l}\text { Aw/oD, } \\
184 \mathrm{~m}\end{array}$ & NA & $\begin{array}{l}\text { MZ, GC } \\
\text { Kaposi Sarcoma }\end{array}$ & Polyclonal \\
\hline$\# 20$ & M, 71 & Yes & $\begin{array}{l}\text { Axillary LN } \\
\text { B symptoms }\end{array}$ & R-CHOP & Concomitant FL & Aw/oD,1 m & $\begin{array}{l}\text { Scattered } \\
\text { interfollicular }\end{array}$ & $\begin{array}{l}\text { MZ } \\
\text { Kaposi Sarcoma }\end{array}$ & Clonal \\
\hline \#21 & M, 59 & Yes & $\begin{array}{l}\text { Generalized LN,SMG, effusions } \\
\text { B symptoms }\end{array}$ & $\begin{array}{l}\text { CHOP } \\
\text { cART }\end{array}$ & & $\begin{array}{l}\text { Aw/oD, } \\
27 \mathrm{~m}\end{array}$ & $\begin{array}{l}\text { Scattered } \\
\text { interfollicular }\end{array}$ & $\begin{array}{l}\text { Mantle, GC, } \\
\text { interfollicular }\end{array}$ & Polyclonal \\
\hline \#22 & M, 36 & Yes & $\begin{array}{l}\text { Cervical LN } \\
\text { B symptoms }\end{array}$ & cART & $\begin{array}{l}\text { Tuberculous } \\
\text { meningoencephalitis }\end{array}$ & DwD, $4 \mathrm{~m}$ & $\begin{array}{l}\text { Scattered } \\
\text { interfollicular }\end{array}$ & $\begin{array}{l}\text { MZ, interfollicular } \\
\text { Endothelial cells }\end{array}$ & ND \\
\hline$\# 23$ & M, 33 & Yes & $\begin{array}{l}\text { Axillary LN, HSMG } \\
\text { B symptoms }\end{array}$ & Unknown & & $\begin{array}{l}\text { Aw/oD, } \\
14 \mathrm{~m}\end{array}$ & $\begin{array}{l}\text { Scattered } \\
\text { interfollicular }\end{array}$ & $\mathrm{MZ}$ & NA \\
\hline$\# 24$ & M, 54 & Yes & $\begin{array}{l}\text { Generalized LN, effusions, } \\
\text { SMG } \\
\text { B symptoms }\end{array}$ & $\begin{array}{l}\text { Burkimab } \\
\text { cART } \\
\text { Doxorubicin }\end{array}$ & $\begin{array}{l}\text { Concomitant high-grade } \\
\text { B-cell lymphoma HHV8- }\end{array}$ & $\begin{array}{l}\text { Aw/oD, } \\
117 \mathrm{~m}\end{array}$ & $\begin{array}{l}\text { Scattered } \\
\text { interfollicular }\end{array}$ & $\begin{array}{l}\text { MZ, GC, } \\
\text { interfollicular } \\
\text { Kaposi sarcoma }\end{array}$ & NA \\
\hline$\# 25$ & M, 61 & Yes & $\begin{array}{l}\text { Generalized LN, HSMG } \\
\text { B Symptoms }\end{array}$ & R-COP & & $\begin{array}{l}\text { Aw/oD, } \\
91 \mathrm{~m}\end{array}$ & Negative & $\begin{array}{l}\text { MZ, GC } \\
\text { Kaposi sarcoma }\end{array}$ & Polyclonal \\
\hline$\# 2$ & $\mathrm{M}, 21$ & Yes & $\begin{array}{l}\text { Generalized LN, SMG } \\
\text { B symptoms }\end{array}$ & $\begin{array}{l}\text { Rituximab } \\
\text { cART }\end{array}$ & & $\begin{array}{l}\text { Aw/oD, } \\
15 \mathrm{~m}\end{array}$ & Negative & $\begin{array}{l}\text { MZ, GC, } \\
\text { interfollicular } \\
\text { Endothelial cells }\end{array}$ & ND \\
\hline \#26 & $\mathrm{M}, 33$ & Yes & $\begin{array}{l}\text { Submandibular LN } \\
\text { B symptoms }\end{array}$ & cART & & $\begin{array}{l}\text { Aw/oD, } \\
57 \mathrm{~m}\end{array}$ & $\begin{array}{l}\text { Scattered } \\
\text { interfollicular }\end{array}$ & $\begin{array}{l}\text { MZ, interfollicular } \\
\text { Kaposi sarcoma }\end{array}$ & ND \\
\hline \#27 & M, 75 & No & Unknown & Unknown & & Unknown & Negative & $\mathrm{MZ}$ & ND \\
\hline \#28 & $\mathrm{F}, 77$ & No & $\begin{array}{l}\text { Generalized LN, SMG } \\
\text { B symptoms }\end{array}$ & R-COP & & $\begin{array}{l}\text { Dw/oD, } \\
10 \mathrm{~m}\end{array}$ & $\begin{array}{l}\text { Scattered } \\
\text { interfollicular } \\
\text { Intrafollicular } \\
\text { involvement }\end{array}$ & MZ & Polyclonal \\
\hline \#29 & $\mathrm{M}, 41$ & No & $\begin{array}{l}\text { Generalized LN, constitutional } \\
\text { syndrome } \\
\text { effusion, SMG }\end{array}$ & $\begin{array}{l}\text { Rituximab, } \\
\text { cyclophosphamide }\end{array}$ & & $\begin{array}{l}\text { Aw/oD, } \\
67 \mathrm{~m}\end{array}$ & $\begin{array}{l}\text { Scattered } \\
\text { interfollicular }\end{array}$ & MZ, interfollicular & Polyclonal \\
\hline \#30 & $\mathrm{F}, 66$ & No & $\begin{array}{l}\text { Generalized LN } \\
\text { B symptoms }\end{array}$ & $\begin{array}{l}\text { CHOP } \\
\text { Adriamycin }\end{array}$ & Relapse and progression & DwD, $21 \mathrm{~m}$ & Negative & $\begin{array}{l}\text { MZ, GC } \\
\text { Endothelial cells }\end{array}$ & Polyclonal \\
\hline
\end{tabular}


Table 3 (Continued)

\begin{tabular}{|c|c|c|c|c|c|c|c|c|c|}
\hline \multicolumn{7}{|c|}{ Clinical features } & \multicolumn{2}{|c|}{ HHV status } & \multirow{2}{*}{$\begin{array}{l}\text { Molecular } \\
I G H V\end{array}$} \\
\hline & Gender/age & $H I V$ & Presentation & Treatment & Course & $\begin{array}{l}\text { Outcome, } \\
\text { follow-up }\end{array}$ & $E B V$ & HHV8 & \\
\hline \#31 & $\mathrm{F}, 80$ & No & Unknown & Unknown & \multirow{9}{*}{$\begin{array}{l}\text { New biopsy after two months } \\
\text { with similar histological } \\
\text { features }\end{array}$} & Unknown & Negative & & NA \\
\hline$\# 32$ & $\mathrm{M}, 51$ & No & $\begin{array}{l}\text { Generalized LN, hemolytic } \\
\text { anemia, arthralgias } \\
\text { B svmptoms }\end{array}$ & $\begin{array}{l}\text { Steroids } \\
\text { Rituximab }\end{array}$ & & $\mathrm{DwD}, 0 \mathrm{~m}$ & Negative & $\begin{array}{l}\text { MZ, interfollicular } \\
\text { Kaposi Sarcoma }\end{array}$ & Polyclonal \\
\hline \#33 & $\mathrm{M}, 20$ & Yes & $\begin{array}{l}\text { Generalized LN } \\
\text { B symptoms }\end{array}$ & $\begin{array}{l}\text { CHOP } \\
\text { CART }\end{array}$ & & Aw/oD & $\begin{array}{l}\text { Scattered } \\
\text { interfollicular }\end{array}$ & MZ & ND \\
\hline$\# 34$ & $\mathrm{M}, 71$ & No & $\begin{array}{l}\text { Generalized LN, B symptoms } \\
\text { SMG }\end{array}$ & $\begin{array}{l}\text { Rituximab, } \\
\text { cyclophosphamide } \\
\text { vincristine }\end{array}$ & & Aw/oD,9 m & $\begin{array}{l}\text { Scattered } \\
\text { interfollicular }\end{array}$ & $\begin{array}{l}\text { MZ, GC, } \\
\text { interfollicular } \\
\text { Kaposi Sarcoma }\end{array}$ & ND \\
\hline \#35 & $\mathrm{M}, 40$ & Yes & $\begin{array}{l}\text { Generalized LN } \\
\text { B symptoms }\end{array}$ & $\begin{array}{l}\text { cART } \\
\text { Steroids }\end{array}$ & & Aw/oD, $8 \mathrm{~m}$ & $\begin{array}{l}\text { Scattered } \\
\text { interfollicular }\end{array}$ & $\begin{array}{l}\text { MZ, GC, } \\
\text { interfollicular } \\
\text { Endothelial cells }\end{array}$ & ND \\
\hline$\# 36$ & $\mathrm{M}, 52$ & Yes & $\begin{array}{l}\text { Generalized LN } \\
\text { hypergammaglobulinemia } \\
\text { B symptoms }\end{array}$ & Rituximab & & AwD, $8 \mathrm{~m}$ & $\begin{array}{l}\text { Scattered } \\
\text { interfollicular }\end{array}$ & $\begin{array}{l}\text { MZ, interfollicular } \\
\text { Endothelial cells }\end{array}$ & Polyclonal \\
\hline$\# 37^{\mathrm{a}}$ & $\mathrm{F}, 22$ & Yes & $\begin{array}{l}\text { Generalized LN, effusions, } \\
\text { SMG, B symptoms }\end{array}$ & $\begin{array}{l}\text { R-CHOP } \\
\text { intrathecal RT }\end{array}$ & & $\begin{array}{l}\text { Aw/oD, } \\
64 \mathrm{~m}\end{array}$ & $\begin{array}{l}\text { Scattered } \\
\text { interfollicular }\end{array}$ & $\begin{array}{l}\text { MZ, GC, } \\
\text { interfollicular }\end{array}$ & Polyclonal \\
\hline$\# 10^{\mathrm{a}}$ & $\mathrm{M}, 30$ & Yes & $\begin{array}{l}\text { Supraclavicular LN, SMG, } \\
\text { effusions, } \\
\text { B symptoms }\end{array}$ & $\begin{array}{l}\text { R-CHOP } \\
\text { cART }\end{array}$ & & $\begin{array}{l}\text { Aw/oD, } \\
33 \mathrm{~m}\end{array}$ & Negative & $\begin{array}{l}\text { MZ, GC } \\
\text { Kaposi sarcoma }\end{array}$ & Polyclonal \\
\hline$\# 38^{\mathrm{a}}$ & $\mathrm{M}, 37$ & Yes & B symptoms & - & & DwD, $0 \mathrm{~m}$ & Negative & $\begin{array}{l}\text { MZ, GC, } \\
\text { interfollicular }\end{array}$ & ND \\
\hline
\end{tabular}

Abbreviations: Burkimab, Rituximab, methotrexate, dexametasona, ifosfamide, vincristine, etoposide, Cytarabine; CHOP, Rituximab, cyclophosphamide, doxorubicin, vincristine, prednisone; DwD, Dead with disease; F, female; FL, follicular lymphoma; HSMG, hepatosplenomegaly; R-CP, Rituximab, prednisone and cyclophosphamide; RT, radiotherapy.

aPBR-MCD: plasmablastic-rich multicentric Castleman disease. 
all patients including the type of immunosuppression, prior or concomitant Kaposi sarcoma, clinical symptoms, sites of involvement, treatment, response to therapy, and follow-up. The main clinicobiological characteristics of all the patients are summarized in Table 1.

The study was performed according to the guidelines of the ethic committees of Hospital Clínic and Hospital del Mar.

\section{Immunohistochemistry and Hybridization Studies}

Immunohistochemical studies were carried out in all samples with a panel of monoclonal and polyclonal antibodies reactive in formalin-fixed paraffinembedded tissue sections using a peroxidaselabeled detection system, standard antigen retrieval protocols, and an automated immunostainer (Dako OMNIS, Glostrup, Denmark or BenchmarkXT, Roche Diagnostics, Basel, Switzerland) as previously described..$^{12}$ Detection of the HHV8 was performed using a mouse monoclonal antibody (HHV8-LANA1; clone 13B10; Cell Marque, Hot Springs, AR, USA). EBV was detected by in situ hybridization using Epstein-Barr virus encoded small RNA (EBER1,2) probes (Leica BOND-MAX system; Leica Biosystems Newcastle upon Time, UK).

\section{IGH Gene Rearrangements}

DNA for the study of IGHV and IGK gene rearrangements was extracted from tissue sections using the QIAamp DNA mini kit (Qiagen, Hilden, Germany). Purified DNA was amplified using primers of the Framework Regions 1 and 3 (FR1 and FR3) and JH regions of the immunoglobulin heavy chain gene (IgH-PCR) and of Vk-Jk region of the immunoglobulin kappa light chain gene (IGK), using the BIOMED2 protocol. ${ }^{13}$

\section{Statistical Methods}

Differences among the subgroups of patients were assessed by using the $\chi^{2}$ test (two-tailed). The actuarial survival analysis was performed by the Kaplan and Meier method and log-rank test. Overall survival was calculated according to standard definitions. $^{14}$

\section{Results}

The histological and phenotypic review allowed the classification of the cases in five main categories: (1) HHV8-positive reactive lymphoid hyperplasia; (2) plasmablastic proliferation of the splenic red pulp; (3) multicentric Castleman disease; (4) germinotropic lymphoproliferative disorder; and (5) HHV8-related lymphomas. The main clinical and pathological 
Table 5 Main clinicopathological features of lymphomas

\begin{tabular}{|c|c|c|c|c|c|c|c|c|}
\hline & \multirow[b]{2}{*}{ Gender/age } & \multirow[b]{2}{*}{$H I V$} & \multicolumn{4}{|c|}{ Clinical features } & \multicolumn{2}{|c|}{ HHV status } \\
\hline & & & Presentation & Diagnosis & Treatment & $\begin{array}{l}\text { Outcome, } \\
\text { follow-up }\end{array}$ & $E B V$ & HHV8 \\
\hline$\# 44$ & M, 53 & Yes & $\begin{array}{l}\text { Ascites } \\
\text { B symptoms }\end{array}$ & PEL & $\begin{array}{l}\text { CHOP } \\
\text { MINE/ESHAP } \\
\text { cART }\end{array}$ & DwD, $19 \mathrm{~m}$ & ND & + \\
\hline \#45 & $M, 64$ & No & CSF & PEL & CHOP & DwD, $1 \mathrm{~m}$ & + & + \\
\hline \#46 & $\mathrm{M}, 49$ & No & Pleural effusion, ascites & PEL & Chemotherapy & DwD, $3 \mathrm{~m}$ & - & + \\
\hline$\# 47$ & $\mathrm{M}, 76$ & Yes & Pleural effusion & PEL & $\begin{array}{l}\text { COP } \\
\text { CART }\end{array}$ & $\mathrm{DwD}, 1 \mathrm{~m}$ & + & + \\
\hline$\# 48$ & M, 39 & Yes & $\begin{array}{l}\text { Pleural effusión } \\
\text { Nodal KS }\end{array}$ & PEL & R-CHOP & DwD, $2 \mathrm{~m}$ & ND & + \\
\hline \#49 & M, 68 & No & Pleural effusion & PEL & CTX & $\mathrm{DwD}, 0 \mathrm{~m}$ & + & + \\
\hline$\# 50$ & $\mathrm{M}, 46$ & Yes & $\begin{array}{l}\text { Pleural effusion } \\
\text { Nodal KS }\end{array}$ & PEL & CHOP & $\begin{array}{l}\text { Relapse after } 1 \\
\text { year } \\
\text { Aw/oD, } 59 \mathrm{~m}\end{array}$ & + & + \\
\hline$\# 51$ & M, 49 & Yes & $\begin{array}{l}\text { Ascites } \\
\text { B symptoms }\end{array}$ & PEL & CHOP & DwD, $2 \mathrm{~m}$ & + & + \\
\hline$\# 13$ & $\mathrm{M}, 42$ & Yes & $\begin{array}{l}\text { Pleural effusion, ascites } \\
\text { Axillary LN }\end{array}$ & PEL & $\begin{array}{l}\text { R-CMyOP } \\
\text { ESHAP }\end{array}$ & AwD, $6 \mathrm{~m}$ & - & + \\
\hline \#52 & $M, 62$ & Yes & $\begin{array}{l}\text { Generalized LN, SMG Constitutional } \\
\text { syndrome }\end{array}$ & Extracavitary PEL & $\begin{array}{l}\text { COP } \\
\text { cART }\end{array}$ & $\mathrm{DwD}, 1 \mathrm{~m}$ & + & + \\
\hline$\# 53$ & M, 49 & Yes & $\begin{array}{l}\text { Generalized LN, subcutaneous mass, } \\
\text { SMG } \\
\text { B symptoms }\end{array}$ & Extracavitary PEL & $\begin{array}{l}\text { CHOP } \\
\text { MTX intrathecal }\end{array}$ & Aw/oD, $35 \mathrm{~m}$ & ND & + \\
\hline$\# 54$ & $\mathrm{M}, 36$ & Yes & Duodenal mass & Extracavitary PEL & Chemotherapy & DwD, $1 \mathrm{~m}$ & + & + \\
\hline$\# 55$ & M, 32 & Yes & Mesenteric LN proctitis, B symptoms & Extracavitary PEL & $\begin{array}{l}\text { CTX, PDN } \\
\text { R-CHOP } \\
\text { cART }\end{array}$ & AwD, $18 \mathrm{~m}$ & + & + \\
\hline \#56 & $M, 49$ & Yes & $\begin{array}{l}\text { Bilateral suprarrenal masses, SMG } \\
\text { B symptoms }\end{array}$ & Extracavitary PEL & $\begin{array}{l}\text { CHOP } \\
\text { cART }\end{array}$ & $\mathrm{DwD}, 5 \mathrm{~m}$ & + & + \\
\hline \#57 & $M, 42$ & Yes & & Extracavitary PEL & & & + & + \\
\hline \#58 & $\mathrm{M}, 44$ & Yes & $\begin{array}{l}\text { Generalized LN, B symptoms, effusions, } \\
\text { SMG }\end{array}$ & HHV8 DLBCL & CTX & DwD, $0 \mathrm{~m}$ & + & + \\
\hline \#59 & M, 63 & No & SMG & HHV8 DLBCL & $\begin{array}{l}\text { Splenectomy } \\
\text { R-CHOP }\end{array}$ & Dw/oD, $34 \mathrm{~m}$ & - & + \\
\hline
\end{tabular}

Abbreviations: CMyOP, rituximab, cyclophosphamide, vincristine, prednisone, doxorubicin; CSF, cerebrospinal fluid; CTX, Cyclophosphamide; DLBCL, diffuse large B-cell lymphoma; MINE, mesna, ifosfamide, mitoxantrone, and etoposide alternated with ESHAP, etoposide, methylprednisolone, high-dose cytarabine and cisplatin; MTX, methotrexate; KS, Kaposi sarcoma; PDN, prednisone.

characteristics of these groups are described separately and summarized in Tables $2-5$.

\section{HHV8-Related Reactive Lymphoid Hyperplasia in HIV Patients}

Histological, immunophenotypic, and molecular features. We investigated the presence of HHV8 in a series of 50 cases diagnosed as HIV-associated reactive lymphadenitis and identified 13 (26\%) cases harboring HHV8-positive cells. The overall architecture of the lymph nodes was preserved with opened sinuses and at least partially recognized lymphoid follicles. Two different histological patterns were identified. Nine cases showed typical features of follicular and paracortical hyperplasia with folliculolysis (Figure 1a), and four cases had marked lymphoid depletion with completely 'burnt out' follicles and prominent stromal cell proliferation (Figure 1c). Scattered HHV8-positive cells were seen in all cases, either in the interfollicular areas, mantle zones or inside the germinal centers (Figure 1b and d). Unlike multicentric Castleman disease none of the cases of HHV8-related reactive lymphoid hyperplasia exhibited follicles with vascular proliferation, thick and hyalinized walls, or hyalinization of germinal centers. Massive interfollicular plasmacytosis was not observed in any case. Five cases also exhibited scattered endothelial HHV8-positive cells. Additionally, four cases showed overt Kaposi sarcoma in the same lymph node capsule. In one case, the follicular dendritic cells in the germinal centers showed cytoplasmic positivity for HHV8 (Figure 1b). Scattered EBV-positive small lymphocytes were observed in 10 out of the 11 cases analyzed. One case also had reactive germinal centers massively infected by EBV. Although double stains were not performed, the different topographic distribution of the HHV8 and EBV-positive cells did not suggest coinfection. 

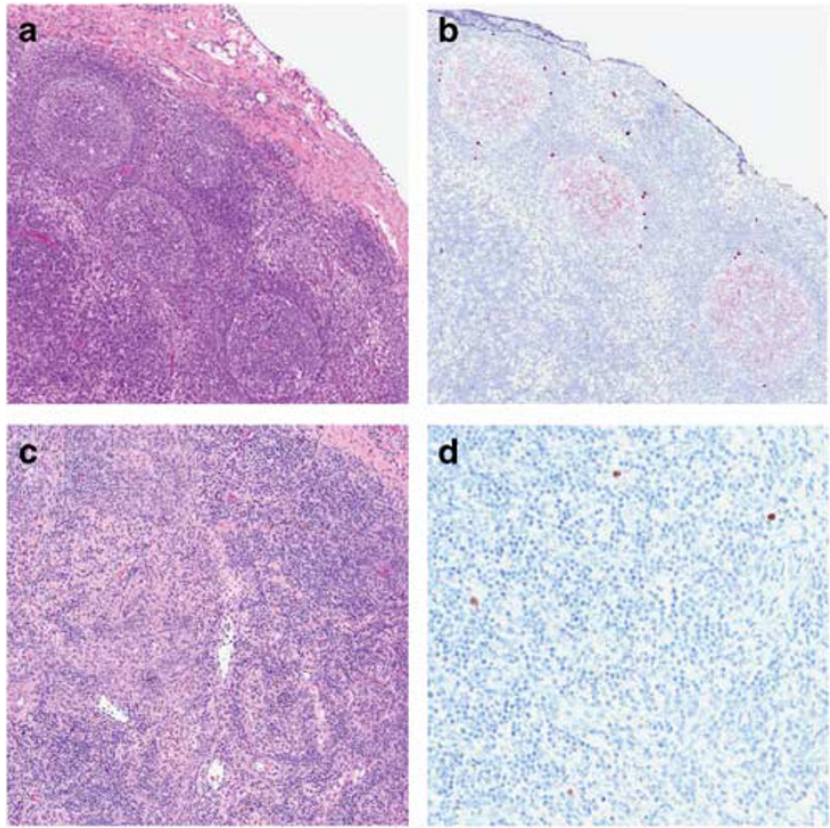

Figure 1 Histologic features of HHV8-related reactive lymphoid hyperplasia. (a, H\&E) Case \#13, reactive follicular hyperplasia showing (b, HHV8-LANA1) HHV8-positive cells in the mantle zones and cytoplasmic dendritic cell staining. (c, H\&E) Case \#12, reactive lymph node with 'burnt out' follicles and prominent stromal cell proliferation also displaying (d, HHV8-LANA1) scattered HHV8-positive lymphoid cells (original magnifications: $\times 40(\mathbf{a}, \mathbf{c})$ and $\times 100(\mathbf{b}, \mathbf{d}))$.
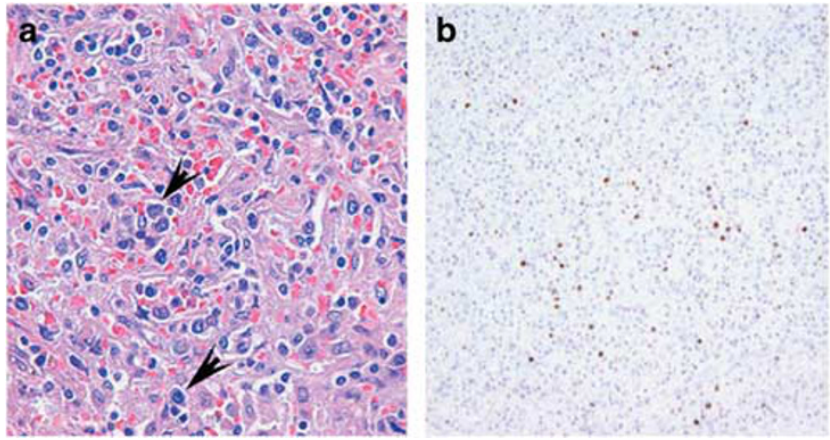

Figure 2 Histologic features of HHV8-positive plasmablastic proliferation of the splenic red pulp. (a, H\&E) Presence of plasmablasts inside splenic sinuses positive for (b, HHV8-LANA1) HHV8 stain (original magnifications: $\times 400($ a) and $\times 100($ b)).

Four patients had consecutive or simultaneous biopsies during the follow-up. Three patients had simultaneous or subsequent multicentric Castleman disease and one patient had a concomitant HHV8positive primary effusion lymphoma that was negative for EBV.

Molecular studies for IGHV rearrangements were performed in five cases. Four were polyclonal and one showed a monoclonal peak in FR2 region consistent with clonality. After review, no morphological evidence of lymphoma was seen in that particular case.
Clinical features. All patients were male, median age 37 years (range, 20-44 years), and median time from the HIV-infection diagnosis to the lymph node biopsy of 27 months (1-167). Lymph node enlargement in more than one area was observed in nine patients and four of them also had splenomegaly. B symptoms were present in seven patients and one patient had also increased lactate dehydrogenase levels. All but two patients were treated with combined antiretroviral therapy and three patients also received chemotherapy. One patient received doxorubicin for Kaposi sarcoma and another, initially diagnosed as multicentric Castleman disease, was treated with immunochemotherapy and splenectomy. The spleen did not show any features of multicentric Castleman disease and after review the initial lymph node biopsy was re-considered as HHV8-related reactive lymphoid hyperplasia. The last patient received immunochemotherapy due to simultaneous primary effusion lymphoma. After a median follow-up of 38 months (5-95 months) all patients except the one with concomitant primary effusion lymphoma have recovered of all symptoms and have no evidence of disease.

\section{HHV8-Positive Plasmablastic Proliferation of the Splenic Red Pulp}

Histological, immunophenotypic, and molecular features. Two cases were included in this category. Both cases had large spleens (over $1000 \mathrm{~g}$ ), one from a surgical splenectomy and the second from an autopsy. The overall architecture was preserved with expanded white pulp and scattered large atypical plasmablasts in the red pulp sinuses and cords with few of them also in the white pulp. Both cases had myeloid metaplasia. No histological evidence of multicentric Castleman disease was identified. HHV8 stain highlighted the intrasinusoidal-positive plasmablasts (Figure 2). HHV8-positive cells were also occasionally seen in the reactive white pulp in both cases. The EBV in situ hybridization showed scattered positive intrasinusoidal small lymphocytes. Clonality analysis for IGHV showed a monoclonal peak in FR2 region in one case and a polyclonal pattern in the FR3 region in the autopsy case. No evidence of any other lymphoid lesions was observed at the autopsy in the second patient.

Clinical features. One patient was a 44-year-old male without relevant past medical history and recent HIV diagnosis (4 months ago) and Kaposi sarcoma, who presented with very low CD4 counts (4 cells/ml), high viral load (157200 copies/ml), fever, giant splenomegaly, and pancytopenia. After splenectomy, he received four cycles of rituximab and was alive without evidence of disease after 40 months of follow-up. The second patient was a 36-year-old man with an 8-year history of HIV infection. The patient discontinued combined antiretroviral 

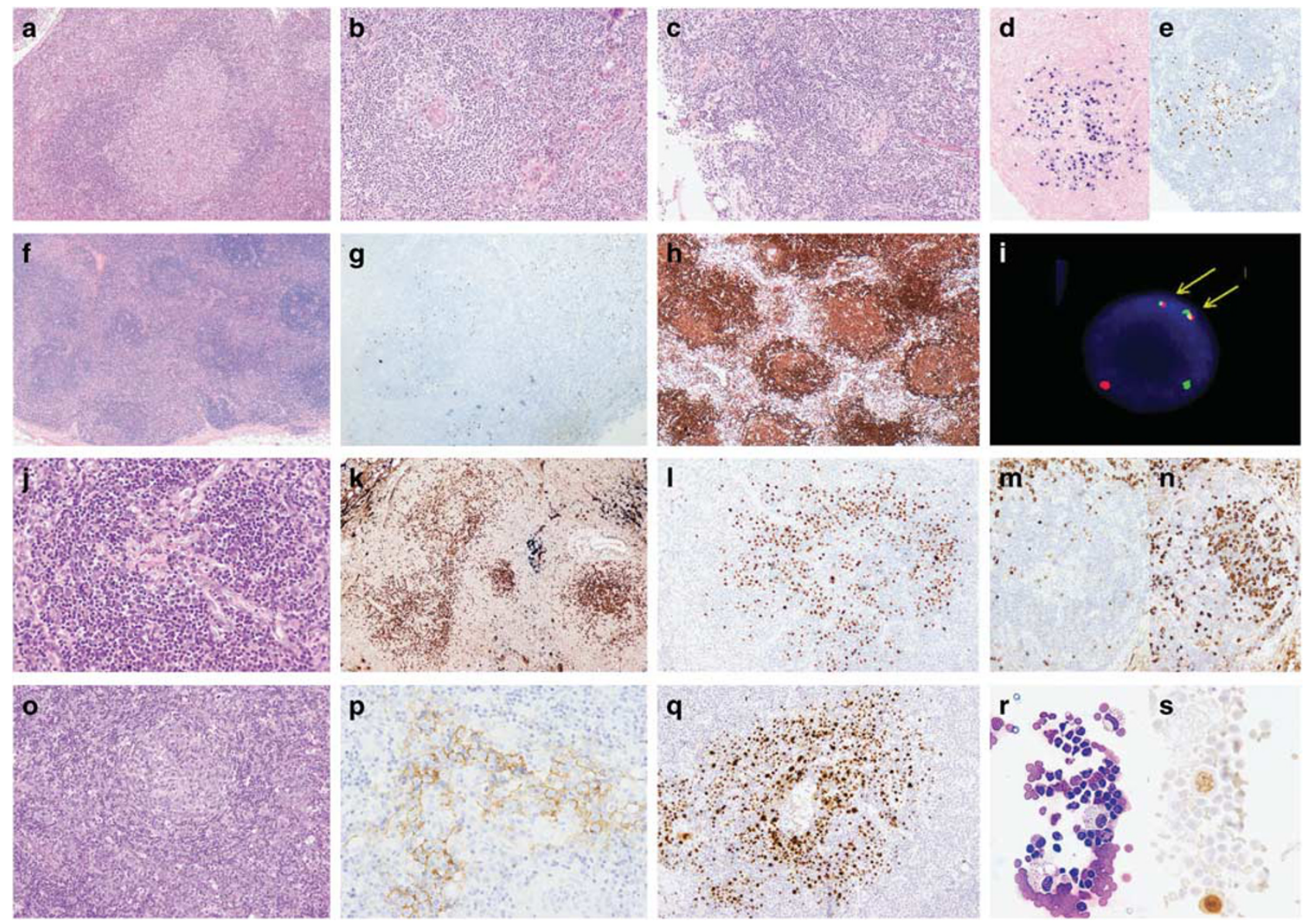

$\mathbf{S}$

Figure 3 Histologic features of multicentric Castleman disease. (a-e) Case \#15 of multicentric Castleman disease with typical features. (a, H\&E) Hyalinized germinal centers are enclosed by a common mantle zone. (b, H\&E) Atrophic follicle with hyalinized germinal center shows penetrating venule. Interfollicular plasmacytosis and prominent vascularization is also observed. (c, H\&E) In the same lymph node, only one ill defined and depleted follicle was present and showed coinfection by (d, EBER) EBV and (e, HHV8-LANA1) HHV8. (f-i) Case \#20 of multicentric Castleman disease with concomitant grade 1 follicular lymphoma. (f, H\&E) Neoplastic-depleted follicles are surrounded by prominent interfollicular expansion with vascular proliferation and plasmacytosis. (g, HHV8-LANA1) HHV8-positive cells are found in the follicles and in the Kaposi sarcoma cells. (h, BCL2) All germinal centers are strongly positive for BCL2 and (i) FISH dual color dual fusion studies highlighted the presence of $\mathrm{t}(14 ; 18)$ translocation. (j-n) Case \#10 of plasmablast-rich multicentric Castleman disease. (j, H\&E) Atrophic and highly vascularized germinal center are found with prominent mantle zones that intrude into the germinal centers. (k, IgD) IgD stain highlights the mantle zone proliferation with (l, HHV8-LANA1) the presence of large HHV8-positive cells with (m, Kappa light chain; n, lambda light chain) lambda light chain restriction. (o-s) Case \#37 plasmablast-rich multicentric Castleman disease with (o, H\&E) preserved follicles and expanded mantles show a high number of plasmablasts. (p, CD21) The CD21 staining highlights the partially disrupted follicular dendritic cell meshwork. (q. HHV8-LANA1) HHV8 staining revealed the presence of high number of plasmablasts limited to the follicles. No sheets of neoplastic cells are found. (r. Giemsa) Pleural effusion shows scattered plasmablasts. (s, HHV8) HHV8-positive in a background of small lymphocytes and histiocytes (original magnifications: $\times 40$ (f), $\times 100$ (b, c, $\mathbf{g}, \mathbf{h}, \mathbf{k}, \mathbf{o}), \times 200(\mathbf{a}, \mathbf{d}, \mathbf{e}, \mathbf{j}, \mathbf{l}-\mathbf{n}, \mathbf{q}), \times 400(\mathbf{p})$, and $\times 600(\mathbf{r}, \mathbf{s}))$.

therapy and had very low CD4 counts ( 1 cell/ml) and high viral load (>50 000 copies $/ \mathrm{ml}$ ). He developed severe pancytopenia and disseminated Kaposi sarcoma with mycoplasma infection and died few days after admission to the hospital.

\section{Multicentric Castleman Disease HHV8-positive}

Histological, immunophenotypic, and molecular features. Twenty-eight cases fulfilled criteria for multicentric Castleman disease, with abnormal follicles with plasmablasts in the mantle zones and marked vascular proliferation with striking plasmacytosis in the interfollicular area. In nine cases $(32 \%)$, the follicular architecture was difficult to assess on H\&E due to a prominent vascular proliferation with marked regressive follicles that were only evident with the follicular dendritic cell staining. As expected, the plasmablasts were strongly positive for IgM with lambda light chain restriction in all cases whereas the interfollicular plasma cells were polytypic. All cases had atypical HHV8-positive plasmablasts in the mantle zone and in 16 cases positive cells in the germinal centers were also observed (Figure 3). Cytoplasmic HHV8 positivity in follicular dendritic cells was observed in five cases. 
EBV-positive small lymphocytes were detected in the interfollicular areas of 18 cases, but the total number of EBV infected cells was usually low $(<5$ cells in 10 high-power field). However, one case also exhibited a solitary germinal center with coinfection of EBV and HHV8, mimicking a germinotropic lymphoproliferative disorder. Nevertheless, the coinfected cells lacked immunoblastic morphology and only partially filled the regressive follicle. The remaining follicles of the node had the typical features of multicentric Castleman disease (Figure 3a-e).

Three cases had atypical multicentric Castleman disease features with an overgrowth of plasmablasts reminiscent of a germinotropic lymphoproliferative disorder or microlymphoma arising in multicentric Castleman disease (Figure 3j-s). All three cases had regressive follicles with mantles zones intruding and replacing the germinal centers accompanied with interfollicular plasmacytosis and vascular proliferation. Although high number of intrafollicular IgM lambda plasmablasts was identified, the germinal centers were not massively replaced and EBV was negative in all cases. None of these cases had shedding of plasmablasts replacing the normal nodal architecture and we thoughtfully named these cases as plasmablast-rich multicentric Castleman disease.

Six cases presented with effusions and cytological specimens were available in five cases, three corresponding to classical multicentric Castleman disease and two of plasmablast-rich multicentric Castleman disease. Very few HHV8-positive plasmablasts were detected in one case of multicentric Castleman disease and in both cases of plasmablastrich multicentric Castleman disease in a background of reactive small lymphocytes. None of them had features of primary effusion lymphoma (Figure 3r-s).

In five patients consecutive biopsies were performed during the follow-up of their disease. Four patients had simultaneous or subsequent lymphomas, one primary effusion lymphoma, two highgrade B-cell lymphomas, not otherwise specified, and one follicular lymphoma. One patient had two biopsies in a 2-month period with similar histological features. The concomitant follicular lymphoma was grade 1, positive for the $t(14 ; 18)$ and BCL2 overexpression, and the tumor cells were negative for EBV and HHV8 (Figure 3f-i). The bone marrow showed infiltration by follicular lymphoma and scattered interstitial HHV8-positive cells. Concomitant Kaposi sarcoma was found in 11 cases and scattered HHV8-positive endothelial cells without evidence of Kaposi sarcoma were seen in five additional cases.

IGHV gene rearrangement was successful in 16 cases. A monoclonal rearrangement was only found in the case with concomitant follicular lymphoma. All remaining cases were polyclonal, including two of three plasmablast-rich multicentric Castleman disease cases.
Clinical features. Twenty-four patients were male and four female (median age, 43 years; range, 20-80 years). Twenty-one cases were HIV positive (75\%) with a median time since the HIV diagnosis to the lymph node biopsy of 18 months (0-182); $40 \%(8 / 21)$ developed the disease during the first year after the diagnosis of HIV infection. At the time of biopsy, 14 patients had low CD4 counts $(<200 /$ $\mathrm{mm}^{3}$ ) and/or high HIV viral load ( $>20000$ copies/ml). Among HIV-negative patients, two had a potential underlying cause of immunosuppression: one patient had a systemic lupus erythematosus treated with immunosuppressive drugs and the other patient received chemotherapy for a colon adenocarcinoma. Four additional HIVnegative patients were aged more than 65 years old and immunosenescence could induce certain level of immunosuppression. Eighteen patients presented with lymphadenopathies involving more than one region and 13 also had splenomegaly. Systemic inflammatory symptoms were observed in 22 patients. Fifteen patients were treated with chemotherapy and 10 with rituximab. Three cases only received rituximab. Four patients were only treated with combined antiretroviral therapy and/or steroids, two of them because of poor performance status and they died shortly after diagnosis.

\section{Germinotropic Lymphoproliferative Disorder HHV8-Positive}

Histological, immunophenotypic, and molecular features. Six lesions from five patients were included in this category. All cases had overall preserved architecture with follicular involvement by a plasmablastic proliferation mainly confined to the germinal centers but with some extension to the adjacent areas (Figure 4a-d). Prominent polytypic plasmacytosis was present in the expanded interfollicular areas of all cases. The expression of B-cell markers in the plasmablastic proliferation was heterogeneous, being either weakly positive or negative for CD20 and CD79a. One case had focal expression of CD138. Three cases coexpressed CD3 but other T-cell markers were negative. All cases were positive for IRF4. Coinfection of HHV8 and EBV in the same tumor cells, as previously described, was observed in five samples, but one case was EBV negative. In this case, the tumor cells were confined into the germinal center and the dendritic cell meshwork was displaced to the periphery of the follicle. The tumor cells expressed kappa light chain restriction (Figure $4 \mathrm{e}-\mathrm{h}$ ).

Molecular studies for IG rearrangements were performed in all six samples. Three cases were polyclonal for IGHV and two were clonal, one in Vk-Jk and the other in FR3 region. T-cell receptor clonal rearrangements were not detected in any case. 

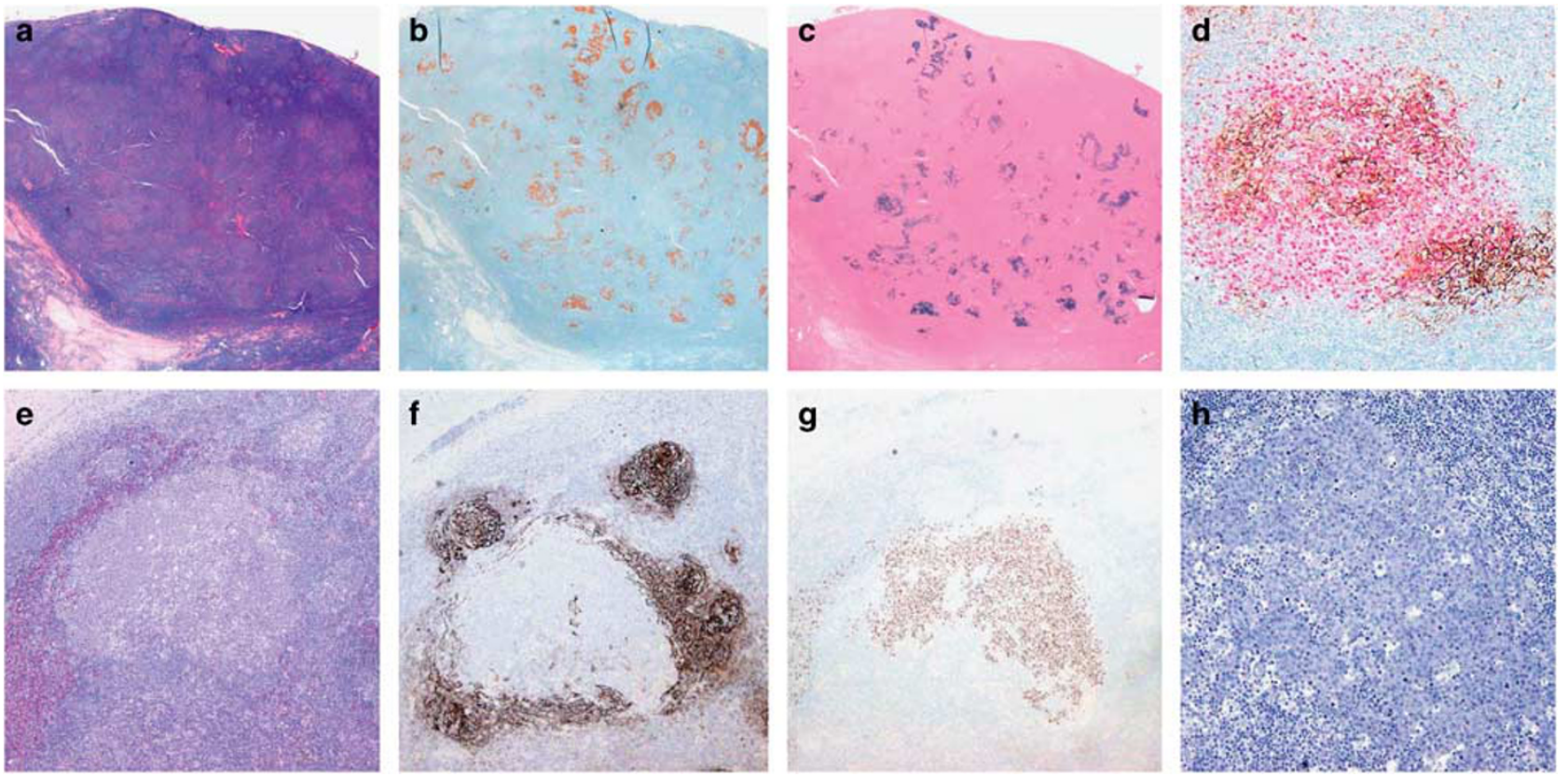

Figure 4 Histologic features of germinotropic lymphoproliferative disorder. (a-d) Case \#42 of germinotropic lymphoproliferative disorder in an HIV patient with (a, H\&E) overall preserved architecture and expanded follicles filled with (b, HHV8-LANA1) HHV8 and (c, EBER) EBV-positive plasmablasts. (d, CD21 and HHV8-LANA1) Double stain for HHV8 and CD21 highlights the partial disruption of the follicular dendritic cell network. (e-h) Case\#39 of EBV-negative germinotropic lymphoproliferative disorder in an HIV-negative patient. (e, H\&E) The enlarged germinal centers are replaced by plasmablastic cells that coalesce and form clusters limited to the germinal center. (f, CD21) CD21 staining shows that HHV8-positive cells occur within a follicular dendritic cell meshwork disrupted and pushed out at the periphery. (g, HHV8-LANA1) The plasmablasts are positive for HHV8 but (h, EBER) negative for EBV (original magnifications: $\times 20$ (a-c), $\times 40(\mathbf{e}-\mathbf{g}), \times 100(\mathbf{d})$, and $\times 200(\mathbf{h})$.
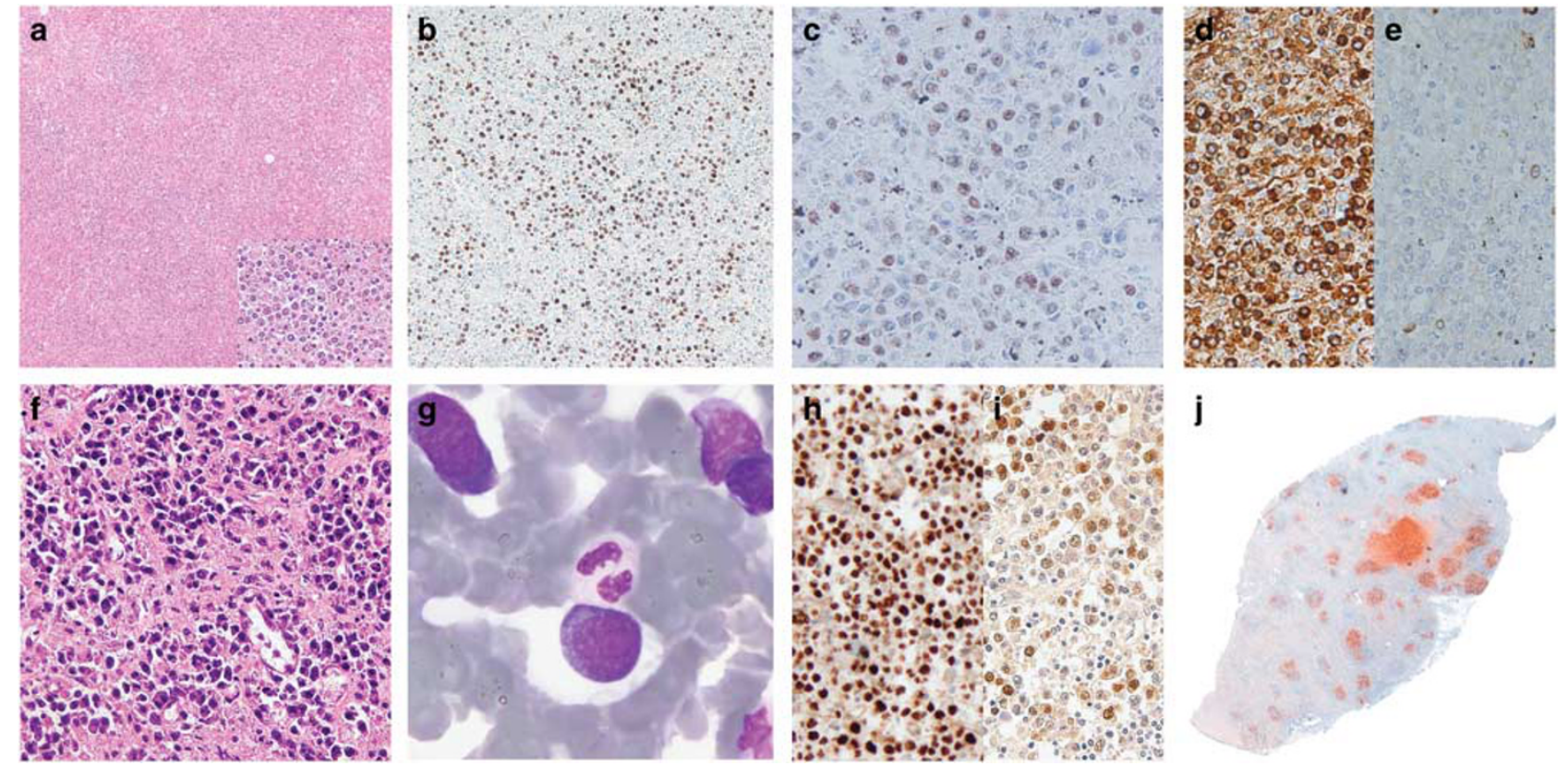

Figure 5 Histologic features of HHV8 lymphomas. (a-e) Case\#59 of primary splenic HHV8-positive lymphoma (a, H\&E) Effacement of the splenic architecture by large atypical plasmablasts (b. HHV8-LANA1) positive for HHV8 and (c, Blimp1) with expression of PRDM1/ BLIMP1, a transcription factor associated with plasma cell differentiation. (d, lambda; e, kappa) The tumor cells showed clear lambda light chain restriction. (f-j) Case\#58 of HHV8-positive lymphoma. (f, H\&E) Pericardial involvement by sheets of atypical plasmablasts with extensive necrosis. (g, Giemsa) Peripheral blood showed leukemic involvement by large atypical plasmablasts with eccentric nuclei (h, HHV8-LANA1) The tumor cells were positive for HHV8 (i, EBER) and some of them also coexpressed EBV. (j, HHV8-LANA1) At autopsy, one of the lymph nodes showed partially preserved architecture with HHV8-infected cells limited inside the follicles mimicking germinotropic lymphoproliferative disorder (original magnifications: ×1 (j), × 100 (a), × 200 (b), $\times 400(\mathbf{c}-\mathbf{f}, \mathbf{h}-\mathbf{i})$, and $\times 1000(\mathbf{g})$ ). 
Clinical features. All patients were male, with a median age of 47 years (27-86 years). Three were HIV positive, with a median time from the HIV diagnosis of 59 months (35-88 months). These patients presented with atypical features such as generalized lymphadenopathy and B symptoms and were treated with chemotherapy. One of them was initially only treated with rituximab and achieved partial response with later disease progression. A new biopsy under progression revealed similar features and the patient received then chemotherapy. After a median follow-up of 12 months, all three patients were alive, one of them with persistence of disease.

Two patients were HIV negative. One was an 86year-old man with large localized cervical adenopathy. The patient did not receive any additional treatment and at 3 months of follow-up remained with stable disease. The last patient was a 52-yearold man with localized inguinal disease for 3 years without B symptoms. After the diagnosis the patient was treated with chemotherapy regimen including ciclofosfamide, doxorubicin, vincristine and prednisone. Follow-up was not available.

\section{HHV8-Positive B-Cell Lymphomas}

Histological, immunophenotypic, and molecular features. We identified 17 cases with overt HHV8positive B-cell lymphoma. Fifteen were primary effusion lymphoma, nine patients presenting with pleural effusion and/or ascites and six patients as mass-forming lesions (extracavitary primary effusion lymphoma). Interestingly, one case presented exclusively with cerebrospinal fluid involvement. All cases exhibit immunoblastic or plasmablastic features with immunophenotypic features of plasma cell differentiation (IRF4+, CD138+ and negative or weak expression of mature B-cell markers). Ten of 13 cases studied were coinfected with EBV. Aberrant expression of CD3 was seen in four cases. Three cases had variable expression of CD30 and one of them also coexpressed CD15. Six of the 15 patients had lymph node enlargement. Two of them showed massive infiltration by Kaposi sarcoma, one case had a massive and exclusive sinusoidal involvement by lymphoma cells and three cases had a reactive follicular hyperplasia, only one with HHV8positive cells.

The other two overt HHV8-positive lymphomas had particular features. One of them could correspond to the new World Health Organization category, HHV8-positive diffuse large B-cell lymphoma, not otherwise specified. In this patient, the lymphoma involvement was limited to the spleen which had a complete effacement of the architecture by a diffuse proliferation of large atypical HHV8positive, EBV-negative cells with plasmablastic differentiation. (Figure 5a-e) Residual areas of multicentric Castleman disease or germinotropic

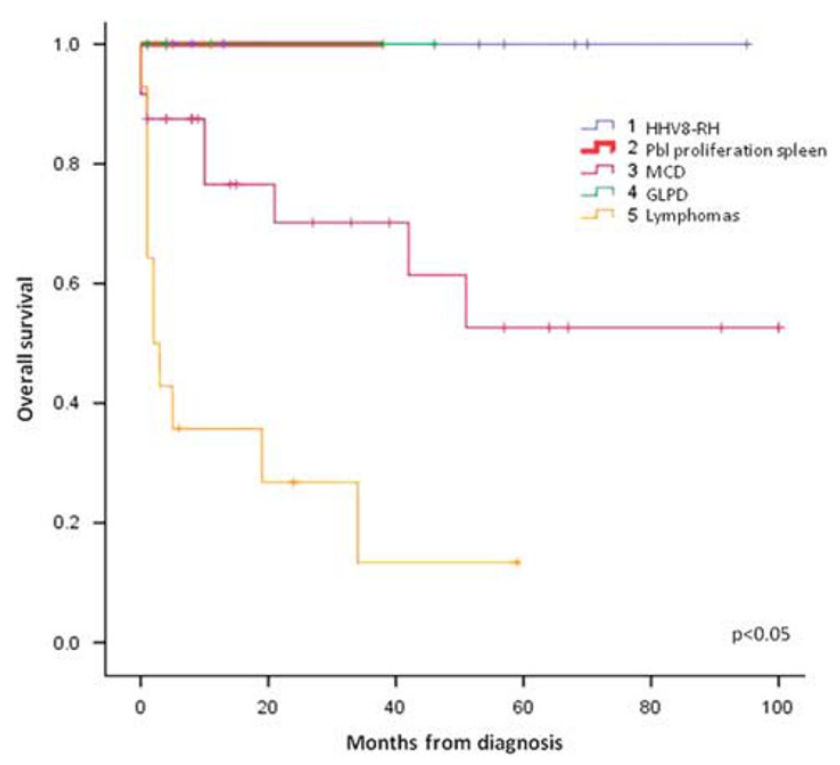

Figure 6 Overall survival by pathology subgroup.

lymphoproliferative disorder were not detected. The atypical cells expressed cytoplasmic IgM lambda and were focally positive for CD79a and IRF4 with strong PRDM1/BLIMP1 expression.

The last case had morphologic features that did not fulfill the criteria for any of previously described B-cell malignancies associated with HHV8 infection. It was a widespread disease with aggressive behavior and leukemic, nodal, hepatosplenic, bone marrow, and pericardial involvement. At autopsy, a large cell lymphoma with immunoblastic features was observed in all these sites (Figure 5f-g). Although in some cells EBV and HHV8 coinfection was observed, the numbers of HHV8-infected cells outnumbered the EBV-positive cells (Figure 5h-l). Intriguingly, one lymph node showed also residual follicles exhibiting features reminiscent of germinotropic lymphoproliferative disorder, raising the possibility of a transformation from germinotropic lymphoproliferative disorder (Figure 5j).

Clinical features. All primary effusion lymphoma patients were male with a median age of 49 years; range, 32-76 years. All patients were immunosuppressed: 12 patients were HIV positive; one has a prior history of liver transplantation 10 months ago, one was under steroid therapy for interstitial lung disease and the last patient was previously treated for a Hodgkin lymphoma and colorectal carcinoma. All patients received chemotherapy and 10 died with a median survival of 2 months (0-19 m).

The patient with HHV8+ diffuse large B-cell lymphoma, not otherwise specified, was an HIV-negative 63 years old male. The patient had splenomegaly and B symptoms and was staged as I-E and thus treated with splenectomy and four cycles of rituximab plus ciclofosfamide, 
doxorubicin, vincristine, and prednisone. He recovered from all symptoms and the patient died of cardiac arrest 3 years after the diagnosis with no evidence of lymphoma.

The last patient with overt aggressive lymphoma was a 44-year-old HIV male who presented with malaise and pericardial effusion. The patient died without receiving any chemotherapy due to rapidly progressive disease and respiratory failure.

\section{Comparative Analysis Between HHV8-Related Pathological Groups}

There were no statistical differences in age or gender distribution between groups. As expected, the five HHV8-related pathology subgroups significantly differed in overall survival $(P<0.05$; Figure 6$)$.

\section{Discussion}

Human herpesvirus 8 (HHV8 or KSHV) is a herpesvirus that infects both lymphoid and endothelial cells. The virus drives Kaposi sarcoma and lymphoid neoplasms, especially in immunosuppressed patients mainly in the setting of HIV infection. Similarly to EBV (human herpesvirus 4), ${ }^{15}$ the oncogenic transformation occurs following the initial infection, when the virus establishes a latent phase. As in EBV infection, a variety of lymphoid proliferations from reactive hyperplasia to overt lymphoma may occur. Nevertheless, the wide spectrum of HHV8-related lymphoid lesions, including HHV8-positive reactive conditions, are not fully characterized. Here, we present a series of 66 cases encompassing different HHV8 lymphoproliferative disorders in HIV-positive and -negative patients that have allowed us to identify novel findings including overlapping features among entities, atypical clinical and morphological presentations as well as cases that did not fit in any of the previously described categories, suggesting that the spectrum of HHV8related lymphoid proliferations may be broader than currently recognized.

We recognized 13 cases of reactive lymphoid hyperplasia in the context of HIV infection, in which HHV8-positive plasmablasts were identified. Some of these patients presented clinically with generalized lymphadenopathy and systemic inflammatory symptoms that were reminiscent of the recently described Kaposi sarcoma virus related inflammatory cytokine syndrome (KICS) related to viral IL6 secretion. Although the histological substrate of these lesions is not well characterized, all these cases lacked features of multicentric Castleman disease. ${ }^{16,17}$ In our reactive HHV8+ cases, the serum IL6 levels were not studied and thus we cannot confirm whether they may correspond to KICS. Despite the fact that all our reactive $\mathrm{HHV}^{+}$cases lacked features of multicentric Castleman disease, a subsequent or concomitant biopsy showed a multicentric Castleman disease in three patients. This finding suggests that some of these lesions may either overlap or transform, highlighting the importance of performing nodal biopsies if clinical symptoms persist. It is not easy to asses if these infected cells in these reactive cases are bystander circulating cells or represent an early stage of multicentric Castleman disease since the number of cases is very limited. One of the patients who developed multicentric Castleman disease 2 months later under combined antiretroviral therapy had already infected cells in the reactive mantle zones. However, this pattern is very rare since most of the cases only harbored scattered infected cells in the interfollicular areas and never progressed to multicentric Castleman disease.

We also report two cases of HHV8-positive plasmablastic proliferation of the splenic red pulp in highly immunosuppressed HIV-positive patients. The HHV8-positive cells were mainly detected inside sinuses and cords. Although scattered HHV8 plasmablasts were also seen in reactive white pulp, criteria of any other HHV8-related disorder were not recognized. One of these patients died of disseminated Kaposi sarcoma and no evidence of HHV8 plasmablastic proliferation outside the spleen was observed at autopsy. To our knowledge no previous reports on similar proliferations have been reported. Whether these cases are related to primary splenic presentation of HHV8-positive diffuse large cell lymphoma has to be still elucidated. ${ }^{18}$

The most common lesion in our cohort was multicentric Castleman disease and 21 of the 28 patients were HIV positive. Multicentric Castleman disease in HIV-positive patients usually develops around 3 years after the diagnosis of HIV under longstanding combined antiretroviral therapy and is commonly associated with Kaposi sarcoma. ${ }^{19-21}$ In our series, $40 \%$ of the patients also had nodal Kaposi sarcoma, but multicentric Castleman disease presented shortly after primary HIV infection or even at the time of HIV diagnosis with a median of 18 months (0-182 months). This atypical presentation of our HIV-positive multicentric Castleman disease cases may be due to the introduction of combined antiretroviral therapy that has dramatically modified the natural history of HIV infection. Except for the clinical presentation, all our cases fulfilled the criteria for multicentric Castleman disease.

Peculiarly we found five multicentric Castleman disease cases and one additional case with HHV8related reactive lymphoid hyperplasia with cytoplasmic staining for the latent nuclear antigen of HHV8 (LANA1) in follicular dendritic cells. This finding has already been recognized in the literature. ${ }^{22}$ Dendritic cells play an important role in HHV8 infection and pathogenesis. ${ }^{23,24}$ Myeloid-dendritic cells and macrophages can be infected by HHV8 through DC-SIGN receptor ${ }^{25}$ and follicular dendriticlike cells have shown to express DC-SIGN. ${ }^{26}$ 
Table 6 Main features of published GLPD cases

\begin{tabular}{|c|c|c|c|c|c|c|c|c|c|c|}
\hline \multirow[b]{2}{*}{ Source } & \multicolumn{5}{|c|}{ Clinical features } & \multicolumn{4}{|c|}{ Immunophenotype } & \multirow{2}{*}{$\begin{array}{l}\text { Molecular } \\
\text { IGHV }\end{array}$} \\
\hline & $\begin{array}{l}\text { Gender, } \\
\text { age }\end{array}$ & IS & Presentation & Treatment & Outcome, follow-up & B-cell markers & IRF4 & $K / L$ & $\begin{array}{l}E B V / \\
H H V 8\end{array}$ & \\
\hline Du’02 & $41, \mathrm{M}$ & No & Axillary, cervical LN for 6 years & CHOP & Aw/oD, 7 years & $\begin{array}{l}\text { CD20- } \\
\text { CD79a- }\end{array}$ & ND & $\mathrm{L}$ & $+/+$ & $\begin{array}{l}\text { Dominant } \\
\text { band }\end{array}$ \\
\hline Du’02 & $61, \mathrm{M}$ & No & $\begin{array}{l}\text { Submandibular, inguinal LN for } 4 \\
\text { years }\end{array}$ & $\mathrm{RT}$ & Aw/oD, 15 years & $\begin{array}{l}\text { CD20 - } \\
\text { CD79a - }\end{array}$ & ND & $\mathrm{L}$ & $+/+$ & NA \\
\hline Du’02 & $63, \mathrm{~F}$ & No & Left inguinal \& para aortic & & Unknown & $\begin{array}{l}\text { CD20- } \\
\text { CD79a- } \\
\text { CD138- } \\
\text { CD38+ }\end{array}$ & ND & K & $+/+$ & Polyclonal \\
\hline Seliem’07 & $45, \mathrm{M}$ & HIV & $\begin{array}{l}\text { Generalized LN, effusion, leukemic, } \\
\text { SMG, B symptoms }\end{array}$ & $\begin{array}{l}\text { Prednisone } \\
\text { ATB } \\
\text { Cyclofosfamide }\end{array}$ & DwD & CD20 focal & + & $\mathrm{L}$ & $+/+$ & Polyclonal \\
\hline $\begin{array}{l}\text { D'Antonio '07 } \\
\text { and'11 }\end{array}$ & $60, \mathrm{M}$ & No & Laterocervical LN, B symptoms & No & Aw/oD, 7 years & $\begin{array}{l}\text { CD20-, } \\
\text { CD79a- } \\
\text { CD138- }\end{array}$ & + & $\mathrm{K}$ & $+/+$ & Polyclonal \\
\hline Oh'11 & $75, \mathrm{M}$ & COPD & Submandibular LN & CHOP & Aw/oD, $19 \mathrm{~m}$ & $\begin{array}{l}\mathrm{CD} 20- \\
\mathrm{CD} 138+\end{array}$ & & K & $+/+$ & Polyclonal \\
\hline Courville'14 & $63, \mathrm{~F}$ & $\begin{array}{l}\text { HCV, } \\
\text { HBV }\end{array}$ & $\begin{array}{l}\text { Isolated Mesenteric LN Hemolytic } \\
\text { anemia }\end{array}$ & & $\begin{array}{l}\text { Progression to EBV } \\
\text { +/HHV8+lymphoma } \\
\text { Aw/oD,13 m (8 m after } \\
\text { initial diagnosis) }\end{array}$ & $\begin{array}{l}\text { CD20-, } \\
\text { CD79a- } \\
\text { PAX5 - } \\
\text { CD138- }\end{array}$ & + & $\mathrm{L}$ & $+/+$ & \\
\hline Papoudou-Bai'15 & $53, \mathrm{M}$ & No & Cervical, supraclavicular LN & Unknown & Unknown & $\begin{array}{l}\text { CD79a-, } \\
\text { CD38- } \\
\text { CD138- }\end{array}$ & + & & $+/+$ & \\
\hline
\end{tabular}

Abbreviations: COPD, chronic obstructive pulmonary disease; HBC, hepatitis B virus; HCV, hepatitis C virus; IS, immunosuppression. 
However, we do not know whether this pattern of staining is specific.

Interestingly, we also identified three atypical multicentric Castleman disease cases that were enriched in the number of plasmablasts. All these cases had a massive proliferation of plasmablasts in the follicles with a highly disrupted follicular dendritic cell meshwork. Only with staining of residual IgD-positive mantle zone cells the follicles became apparent. The differential diagnosis with HHV8-positive germinotropic lymphoproliferative disorder could be challenging. Nevertheless, in germinotropic lymphoproliferative disorder the follicles are easily identified on H\&E stain and the lesions are usually EBV+. One of our plasmablastrich multicentric Castleman disease exhibited large aggregates of HHV8-positive plasmablasts reminiscent of what have been described as microlymphoma. ${ }^{21}$ None of our cases progressed to over HHV8-associated lymphoma. The differential diagnosis with primary effusion lymphoma could be considered in some of these cases as they may present with effusions with HHV8-infected plasmablasts. However, contrary to primary effusion lymphoma the number of HHV8 cells present in the effusion of these cases is very low and within a reactive background of plasma cells and small lymphocytes.

HHV8-positive germinotropic lymphoproliferative disorder is a non aggressive HHV8-positive lesion that occurs in HIV-negative patients usually with localized disease. ${ }^{7,8}$ Interestingly, some of our cases differ from this particular clinical presentation. Three of our five patients were HIV positive and presented with generalized lymphadenopathy and B symptoms. Since the original description, just eight more cases have been reported (Table 6) and only one of them arose in an HIV-positive patient with a more aggressive clinical course. Histologically, the plasmablastic proliferation in these cases spread outside the germinal center invading the outer zone. Unlike microlymphoma arising in multicentric Castleman disease, our cases involve most of the follicles and the disruption of the follicular dendritic cells is not limited to a single follicle. Moreover, microlymphoma is an EBV unrelated proliferation and the neoplastic cells are always lambda restricted, whereas two of our cases are kappa restricted. Intriguingly, we observed a similar pattern in a partially preserved lymph node of an HIV-positive patient with HHV8-positive large cell lymphoma, suggesting the possibility of a germinotropic lymphoproliferative disorder transformation into an overt lymphoma as previously suggested. ${ }^{9,10}$ Our HIV-negative patients presented with conventional clinical and pathological germinotropic lymphoproliferative disorder features but one of them was EBV negative, an aspect not previously described in this entity. This case did not fulfill the criteria of multicentric Castleman disease, since the patient had localized lymph node enlargement without B symptoms and morphologically the follicles were expanded, filled with plasmablasts and the cells expressed kappa light chain. Similarly to other HHV8-related proliferations ${ }^{27,28}$ but not previously reported in germinotropic lymphoproliferative disorder, three of our five cases aberrantly expressed CD3.

Among HHV8-positive lymphomas we have identified 14 primary effusion lymphoma cases with typical features and three additional cases with some particularities. One HIV patient had a primary effusion lymphoma with a primary cerebrospinal fluid involvement with no effusions or lymph node enlargement. Primary central nervous system involvement by primary effusion lymphoma has been rarely described in HIV-positive patients. ${ }^{29,30}$ Detection of HHV8-positive plasmablasts in the cerebrospinal fluid is the diagnostic feature. One patient had a disseminated HHV8-positive lymphoma presented with lesions reminiscent of germinotropic lymphoproliferative disorder in a partially preserved lymph node. Although we cannot rule out a secondary involvement of the follicles by the tumor, this observation has been rarely recognized, ${ }^{9,10}$ suggesting that some cases of germinotropic lymphoproliferative disorder may progress to overt lymphoma. Finally, we also found an EBV negative, HHV8positive, large cell lymphoma expressing IgM lambda, limited to the spleen in a non-HIV patient. This situation was similarly described in an HIV-positive patient ${ }^{31}$ and may correspond to the new World Health Organization category of HHV8-positive diffuse large B-cell lymphoma, not otherwise specified. ${ }^{8}$

In summary, HHV8-positive lymphoid proliferations are a heterogeneous group of lymphoid proliferations that represent a wide pathological spectrum ranging from reactive hyperplasia to aggressive lymphomas. The results of our study advocate for routine HHV8 testing in all lymphoid proliferations in immusuppressed patients, especially in the setting of HIV infection.

\section{Acknowledgments}

We owe an enormous amount of gratitude to all of the consultant hematologists and pathologists who provided patient samples for this study. AM is supported by Fondo de Investigación Sanitaria (PI14/00333) and FEDER One way to Europe. EC research is supported by the Ministerio de Economía y Competitividad, Grant No. SAF2015-64885-R and Instituto de Salud Carlos III, Red Temática de Investigación Cooperativa en Cáncer (RTICC) grant RD12/0036/0036 and the European Regional Development Fund 'Una manera de fer Europa'. EC is an Academia Researcher of the 'Institució Catalana de Recerca i Estudis Avançats' (ICREA) of the Generalitat de Catalunya. 


\section{Disclosure/conflict of interest}

The authors declare no conflict of interest.

\section{References}

1 Chang Y, Cesarman E, Pessin MS, et al. Identification of herpesvirus-like DNA sequences in AIDS-associated Kaposi's sarcoma. Science 1994;266:1865-1869.

2 Cesarman E, Chang Y, Moore PS et al. Kaposi's sarcoma-associated herpesvirus-like DNA sequences in AIDS-related body-cavity-based lymphomas. N Engl J Med 1995;332:1186-1191.

3 Chadburn A, Hyjek E, Mathew S, et al. KSHV-positive solid lymphomas represent an extra-cavitary variant of primary effusion lymphoma. Am J Surg Pathol 2004;28: 1401-1416.

4 Soulier J, Grollet L, Oksenhendler E, et al. Kaposi's sarcoma-associated herpesvirus-like DNA sequences in multicentric Castleman's disease. Blood 1995;86: 1276-1280.

5 Oksenhendler E, Duarte M, Soulier J, et al. Multicentric Castleman's disease in HIV infection: a clinical and pathological study of 20 patients. AIDS 1996;10:61-67.

6 Ariza-Heredia EJ, Razonable RR. Human herpes virus 8 in solid organ transplantation. Transplantation 2011;92:837-844.

7 Du MQ, Diss TC, Liu H, et al. KSHV- and EBVassociated germinotropic lymphoproliferative disorder. Blood 2002;100:3415-3418.

8 Swerdlow SH, Campo E, Pileri SA, et al. The 2016 revision of the World Health Organization classification of lymphoid neoplasms. Blood 2016;127:2375-2390.

9 Seliem RM, Griffith RC, Harris NL, et al. HHV-8+, $\mathrm{EBV}+$ multicentric plasmablastic microlymphoma in an HIV+ man: the spectrum of HHV-8+ lymphoproliferative disorders expands. Am J Surg Pathol 2007;31: 1439-1445.

10 Courville EL, Sohani AR, Hasserjian RP, et al. Diverse clinicopathologic features in human herpesvirus 8-associated lymphomas lead to diagnostic problems. Am J Clin Pathol 2014;142:816-829.

11 Dojcinov SD, Venkataraman G, Pittaluga S, et al. Agerelated EBV-associated lymphoproliferative disorders in the Western population: a spectrum of reactive lymphoid hyperplasia and lymphoma. Blood 2011;117: 4726-4735.

12 Garcia-Herrera A, Song JY, Chuang SS, et al. Nonhepatosplenic gammadelta T-cell lymphomas represent a spectrum of aggressive cytotoxic T-cell lymphomas with a mainly extranodal presentation. Am J Surg Pathol 2011;35:1214-1225.

13 van Dongen JJ, Langerak AW, Bruggemann M, et al. Design and standardization of PCR primers and protocols for detection of clonal immunoglobulin and T-cell receptor gene recombinations in suspect lymphoproliferations: report of the BIOMED-2 Concerted Action BMH4-CT98-3936. Leukemia 2003;17:2257-2317.

14 Cheson BD, Pfistner B, Juweid ME, et al. Revised response criteria for malignant lymphoma. J Clin Oncol 2007;25:579-586.

15 Gonzalez-Farre B, Rovira J, Martinez D, et al. In vivo intratumoral Epstein-Barr virus replication is associated with XBP1 activation and early-onset post-transplant lymphoproliferative disorders with prognostic implications. Mod Pathol 2014;27:1599-1611.
16 Polizzotto MN, Uldrick TS, Hu D, et al. Clinical manifestations of Kaposi sarcoma herpesvirus lytic activation: multicentric Castleman disease (KSHVMCD) and the KSHV inflammatory cytokine syndrome. Front Microbiol 2012;3:73.

17 Polizzotto MN, Uldrick TS, Wyvill KM, et al. Clinical features and outcomes of patients with symptomatic Kaposi sarcoma herpesvirus (KSHV)-associated inflammation: prospective characterization of KSHV inflammatory cytokine syndrome (KICS). Clin Infect Dis 2016;62:730-738.

18 Hasegawa H, Katano H, Tanno M, et al. BCL-6-positive human herpesvirus 8-associated solid lymphoma arising from liver and spleen as multiple nodular lesions. Leuk Lymphoma 2004;45:2169-2172.

19 Dupin N, Diss TL, Kellam P, et al. HHV-8 is associated with a plasmablastic variant of Castleman disease that is linked to HHV-8-positive plasmablastic lymphoma. Blood 2000;95:1406-1412.

20 Oksenhendler E, Boulanger E, Galicier L, et al. High incidence of Kaposi sarcoma-associated herpesvirusrelated non-Hodgkin lymphoma in patients with HIV infection and multicentric Castleman disease. Blood 2002;99:2331-2336.

21 Schulte KM, Talat N. Castleman's disease-a two compartment model of HHV8 infection. Nat Rev Clin Oncol 2010;7:533-543.

22 El Daly H, Bower M, Naresh KN. Follicular dendritic cells in multicentric Castleman disease present human herpes virus type 8 (HHV8)-latent nuclear antigen 1 (LANA1) in a proportion of cases and is associated with an enhanced T-cell response. Eur J Haematol 2010;84: 133-136.

23 Campbell DM, Rappocciolo G, Jenkins FJ, et al. Dendritic cells: key players in human herpesvirus 8 infection and pathogenesis. Front Microbiol 2014; $5: 452$.

24 Hensler HR, Rappocciolo G, Rinaldo CR, et al. Cytokine production by human herpesvirus 8-infected dendritic cells. J Gen Virol 2009;90:79-83.

25 Rappocciolo G, Jenkins FJ, Hensler HR, et al. DC-SIGN is a receptor for human herpesvirus 8 on dendritic cells and macrophages. J Immunol 2006; 176:1741-1749.

26 Taruishi M, Terashima K, Dewan Z, et al. Role of follicular dendritic cells in the early HIV-1 infection: in vitro model without specific antibody. Microbiol Immunol 2004;48:693-702.

27 Beaty MW, Kumar S, Sorbara L, et al. A biophenotypic human herpesvirus 8-associated primary bowel lymphoma. Am J Surg Pathol 1999;23:992-994.

28 Said JW, Shintaku IP, Asou H, et al. Herpesvirus 8 inclusions in primary effusion lymphoma: report of a unique case with T-cell phenotype. Arch Pathol Lab Med 1999;123:257-260.

29 Ely SA, Powers J, Lewis D, et al. Kaposi's sarcomaassociated herpesvirus-positive primary effusion lymphoma arising in the subarachnoid space. Hum Pathol 1999;30:981-984.

30 Jain S, Palekar A, Monaco SE, et al. Human immunodeficiency virus-associated primary effusion lymphoma: an exceedingly rare entity in cerebrospinal fluid. Cytojournal 2015;12:22.

31 Engels EA, Pittaluga S, Whitby D, et al. Immunoblastic lymphoma in persons with AIDS-associated Kaposi's sarcoma: a role for Kaposi's sarcoma-associated herpesvirus. Mod Pathol 2003;16:424-429. 